\title{
Decision Usefulness of Net Income versus Comprehensive Income: Case of Financial Firms in Malaysia
}

\author{
Chong Leong Yew*, Ahmed Razman Abdul Latiff and Ong Tze San
}

\begin{abstract}
Manuscript type: Research paper

Research aims: This paper aims to examine the decision usefulness of net income (NI) which includes predictive power and value relevance by comparing it with comprehensive income $(\mathrm{CI})$, for financial firms in Malaysia.

Design/Methodology/Approach: This study uses panel data analysis techniques which focus on unbalanced panel dataset of 2012 to 2017, obtained from 29 financial firms listed in Malaysia.

Research findings: Results show that in the case of predictive power tests, there is insufficient evidence to conclude that one accounting metric has better predictive power than the other. In the case of value relevance, results show that NI is better than $\mathrm{CI}$ when using the price and return models. This indicates that NI is more decision useful to investors than CI for financial firms in Malaysia.

Theoretical contribution/Originality: This study expands on the literature of decision usefulness of NI (in comparison to $\mathrm{CI}$ ) for financial firms within an emerging economy, such as Malaysia, which has a smaller and less efficient market. The findings support the agency theory, particularly the Type II agency problem, which show that there is a conflict between controlling and non-controlling
\end{abstract}

\footnotetext{
* Corresponding author: Chong Leong Yew is an Accounting Lecturer at the Xiamen University Malaysia, 43900 Sepang. Email: chonglyew@gmail.com or leongyew.chong@xmu.edu.my Ahmed Razman Abdul Latiff is an Associate Professor at the Putra Business School, Universiti Putra Malaysia, 43400 Serdang. Email: razman@putrabs.edu.my

Ong Tze San is an Associate Professor at the Department of Accounting and Finance, Faculty of Economics and Management, Universiti Putra Malaysia, 43400 Serdang. Email: tzesan@upm. edu.my
}

https://doi.org/10.22452/ajba.vol13no2.8 
shareholders. This outcome may reduce the demand for quality reporting for external shareholders. This study is related to fair value accounting (FVA) which is still underexplored in the Malaysian setting. The outcome may provide some insights into the financial statements used by investors for understanding the effect of FVA on reported earnings in Malaysia. Such evidence is currently lacking.

Practitioner/Policy implications: The findings may be helpful to investors in making better investment decisions in the Malaysian market. This study may benefit academicians by expanding the literature on decision usefulness of FVA in an emerging economy. The outcome derived offers a body of knowledge to academia as a reference for future research. This paper may also be relevant to the standard setters, regulators, and policymakers as it offers empirical evidence on the decision usefulness of accounting information disclosures in the context of an emerging country such as Malaysia.

Research limitation/Implications: The limitation of this study lies in the small sample size used, thereby reducing the generalisability of the findings. Larger sample size may add robustness to the results.

Keywords: Comprehensive Income, Decision Usefulness, Net Income, Predictive Power, Value Relevance

JEL Classification: M41, G14

\section{Introduction}

In 1997, the "Statement of Financial Accounting Standards No. 130" (SFAS 130) "Reporting Comprehensive Income" was adopted in the United States (US) by the Financial Accounting Standards Board (FASB). ${ }^{1}$ The adoption requires companies to present the "statement of comprehensive income" in addition to the statement of income. The purpose was to enhance the transparency and disclosure level so that investors are provided with different financial performance indicators (Kanagaretnam, Mathieu, \& Shehata, 2009). The comprehensive income (CI) is also known as clean surplus income. It consists of "all-inclusive" income which advocates the claim that CI can be used to gauge the performance of firms. It is also noted to be superior to NI because it consists of all net asset changes derived from non-owner sources (Dhaliwal, Subramanyam, \& Trezevant, 1999; Veltri \& Ferraro, 2018).

\footnotetext{
${ }^{1}$ FASB is the "independent, private-sector, not-for-profit organisation that establishes financial accounting and reporting standards for public and private companies and not-for-profit organisations that follow generally accepted accounting principles (GAAP)".
} 
In order to attain convergence with FASB, the International Accounting Standards Board (IASB) ${ }^{2}$ issued a revised "International Accounting Standard No. 1" (IAS 1) "Presentation of Financial Statements" which took effect in 2009. Through the Malaysian Accounting Standards Board (MASB), Malaysia also adopted the "Malaysian Financial Reporting Standards" (MFRS) 101 "Presentation of Financial Statements" which is equivalent to the said IAS 1 (revised 2007). This took effect in 2012 (Tan, 2014). The CI statement includes two components: the profit and loss component (or the net income), and the other comprehensive income (OCI). As stated in the MFRS 101 para 7, the OCI items consist of all unrealised gains and losses arising from: the revaluation of property, plant and equipment, defined benefit pension plans, foreign exchange translation of foreign operations, fair value adjustments for financial instruments such as available-for-sale securities (AFS), effective portion of cash flow hedges (CFH), and net investment hedges (NIH). These items include unrealised fair value changes which were unable to fulfill the criteria to be incorporated in the NI because they were either unrelated to the core earnings, or they were overly volatile (Easton \& Zhang, 2017). In this regard, standard setters permit these items to bypass the statement of income, and to be reported under the OCI (Easton \& Zhang, 2017).

The OCI items which bypassed the statement of income, can be regarded as an extended view of NI. This can act as an alternative financial tool (Tan, 2014). The OCI items may offer valuable information on the amount of unrealised gains and losses which may have an effect on the future performance of a firm. Presumably, this offers investors useful information which may be used to gauge firm performance. However, there are also arguments (Ball, 2006; Chambers, Linsmeier, Shakespeare, \& Sougiannis, 2007; Kanagaretnam et al., 2009; Palea \& Scagnelli, 2017; Veltri \& Ferraro, 2018) claiming that the OCI items do not necessarily provide useful information. Instead, they may cause confusion due to the recognition of unrealised gains and losses which are transitory and volatile in nature. With the adoption of the IAS 1 (revised 2007) which made the presentation of CI statements mandatory, it is uncertain which accounting metric, the $\mathrm{NI}$ or $\mathrm{CI}^{3}$, would be more decision useful to investors. The former, NI, is often used as the

\footnotetext{
${ }^{2}$ IASB is "an independent, private-sector body that develops and approves international financial reporting standards (IFRS)".

${ }^{3} \mathrm{CI}$ is the "sum of all components of profit or loss and OCI" (IAS 1 (revised 2007) para 7).
} 
performance measurement metric by investors (Goncharov \& Hodgson, 2011; Veltri \& Ferraro, 2018) whereas the CI Statement may offer investors with more useful and relevant information for evaluating firm performance (Veltri \& Ferraro, 2018).

\subsection{The Malaysian Context}

Besides being one of Asia Pacific's major financial centre, Malaysia is also one of South East Asia's fastest-growing emerging economies (Muniandy \& Ali, 2012). Malaysia has made tremendous efforts in converging with the IFRS (Muniandy \& Ali, 2012) successfully in 2012. Despite the country's substantial growth in the economy, much of its financial reporting development has been underexplored (Muniandy \& Ali, 2012), particularly on the FVA. Malaysia is unique in that companies listed in Bursa Malaysia are dominated by companies with high ownership concentration structure (Claessens, Djankov, \& Lang, 2000; Haniffa \& Hudaib, 2006; Maigoshi, Latif, \& Kamardin, 2018; Tam \& Tan, 2007). Past studies (Claessens et al., 2000; Haniffa \& Hudaib, 2006; Maigoshi et al., 2018; Tam \& Tan, 2007) have documented that the ownership structure for emerging countries in the Asian region, particularly Malaysia, is more concentrated than developed countries like the United Kingdom (UK), the United States (US), and Europe. This has been endorsed by Claessens et al. (2000) who said that following Thailand and Indonesia, Malaysia is the third highest. Previous studies (Ball, Robin, \& Wu, 2003; Leuz, 2006; Leuz, Nanda, \& Wysocki, 2003) have revealed that countries with higher ownership structures tend to be strongly related to higher earnings management activities. This is mainly because the ownership concentration can induce Type II agency problems, thereby granting major shareholders the privileged access to gain information advantage. This, therefore, curtails the need for quality reporting to external shareholders (Abdullah, Evans, Fraser, \& Tsalavoutas, 2015; Ball et al., 2003; Fan \& Wong, 2002). Abdullah et al. (2015) noted that Malaysia is dominated by Type II agency problems. As such, the decision usefulness of reported earnings in Malaysia may differ significantly from other developed countries that may have dispersed ownership structures.

The quality of financial reporting is not only dependent upon accounting standards but also on other institutional settings (Ball et al., 2003; Holthausen, 2009; Soderstrom \& Sun, 2007), such as legal enforcement. This is because the enforcement power of the standards 
is not determined by the IASB (Ball, 2006; Soderstrom \& Sun, 2007). Moreover, the enforcers are largely locals, hence practices vary across countries. In this regard, the reporting quality would inevitably differ (Ball, 2006). Past studies (Wüstemann \& Kierzek, 2006) have documented that accounting practices tend to be strongly influenced by rules rather than contents of the rules. Other studies (Brown \& Tarca, 2012; Odia \& Ogiedu, 2013; Samaha \& Khlif, 2016) have also indicated that there were compliance gaps in the implementation of the IFRS across the world, particularly in less developed countries. In the case of Malaysia, it appears that legal enforcement is generally weak (Liew, 2007; Muniandy \& Ali, 2012; Tam \& Tan, 2007), hence more earnings management activities. This scenario is less prevalent among countries with stricter legal enforcement (Ball, Kothari, \& Robin, 2000; Leuz et al., 2003). A few studies (Barth, Landsman, \& Lang, 2008) have noted that higher earnings management was correlated with lower decision usefulness of earnings. Given this fact, the decision usefulness of reported earnings in Malaysia may differ significantly from developed countries with stronger legal enforcement (e.g., the US, the UK, and Europe).

Past studies looking at CI had mainly focused on developed countries, particularly the UK, US and Europe where the institutional factors (e.g., legal enforcement and ownership structure) differed significantly from those of less developed countries in the Asian region such as Malaysia. In this regard, the assumption of the superiority of the $\mathrm{CI}^{4}{ }^{4}$ which has higher exposure to FVA, in enhancing the decision-making of investors is still unanswered. Empirical evidence for Malaysia is still lacking, thus a study focusing on the Malaysian context can provide interesting insights into the phenomenon.

This study addresses the above gap by focusing on the stock exchange of Malaysia (Bursa Malaysia). Data as of 31 December 2018 showed that the listed firms in the financial sector in Bursa Malaysia formed about 24 per cent of the total market capitalisation (Bursa Malaysia, 2019), and they remained attractive to investors. The financial sector mainly consists of financial institutions which act as financial intermediaries between suppliers and users of capital in the monetary system. They are important in an economy because the results of these financial institutions reflect the state of the country's real economy. However, the risks within the intermediation process are hardly

\footnotetext{
${ }^{4}$ The CI has higher exposure to FVA because the components of $\mathrm{OCI}$ mainly consist of fair value adjustments (Bratten, Causholli, \& Khan, 2016).
} 
observable by outsiders. This opacity of the financial structure of banks, thus, exposes the institutions to a high possibility of bank runs which can adversely impact the whole economy. This means that the financial sector as an important sector for the economy, particularly for smaller and less efficient emerging markets like Malaysia, needs to be examined.

In addition, the balance sheets of financial firms are structurally different when compared with non-financial firms. The main assets of financial firms are likely made up of financial instrument assets (Barth, Gomez-Biscarri, Kasznik, \& López-Espinosa, 2017; Duh, Hsu, \& Alves, 2012). As such, financial firms are likely to have significant exposures to the financial instrument components of the OCI items, such as AFS, CFH, and NIH. The unrealised fair value changes arising from these financial instrument components are likely to exert a substantial influence on the $\mathrm{CI}$ for the financial sector when compared to nonfinancial sectors (Easton \& Zhang, 2017). Past studies (Al-Yaseen \& Al-Khadash, 2011; Barth, Landsman, \& Wahlen, 1995; Duh et al., 2012) found that the recognition of unrealised fair value changes on financial instruments tends to increase firms' earnings volatility. Therefore, the $\mathrm{CI}$ for financial firms is potentially more volatile than the $\mathrm{CI}$ for non-financial firms. Past findings on non-financial sectors which have less exposure to financial instrument components have been noted to differ significantly from the financial sector. However, as highlighted in the literature review, there is inadequate emphasis being made on the financial sector. Thus, there is no concrete evidence to confirm this subject matter. This study was thus undertaken to fill an important literature gap, which is to establish the empirical evidence on the decision usefulness of $\mathrm{NI}$ in comparison with $\mathrm{CI}$, for the financial sector.

To the best of the authors' knowledge, no past study has examined the decision usefulness of $\mathrm{NI}$ in comparison with $\mathrm{CI}$, particularly for financial firms in Malaysia, following the implementation of the MFRS 101 which is equivalent to the revised IAS 1 (revised 2007). This study would thus add to the literature for a smaller and less efficient economy (Gan, Chong, \& Ahmad, 2016). Additionally, this issue is related to the FVA since the components of OCI items mainly comprised of fair value adjustments (Bratten, Causholli, \& Khan, 2016). As research on the FVA is still underexplored in Malaysia, the outcome derived from this study may offer some insights to users of the financial statements such as facilitating their comprehension on the effects of the FVA on the decision usefulness of reported earnings since such evidence is currently lacking. 
This study makes some contributions in the following ways. First, it extends on the literature about the ongoing debate of the relevancy of $\mathrm{CI}$ as a performance measurement metric as compared to the traditional performance measurement metric of NI. To enhance their decisionmaking, investors may be interested in identifying which of these two accounting metrics is superior in measuring firm performance. Second, the findings could influence investors in selecting the relevant accounting metric in order to make better investment decisions. Third, the Malaysian data offer some insightful information about the development of emerging markets in the Asian region. Evidence drawn from the Malaysian context may be applicable to other emerging countries within the Asian region having similar institutional settings. Fourth, this study offers academics with a body of knowledge as a reference for furthering and broadening future research on decision usefulness of OCI items, particularly for the financial sector. Finally, the results may also be relevant to policymakers in Malaysia (e.g., Securities Commission, Bursa Malaysia, Malaysian Institute of Accountants), and standard setters (e.g., IASB and MASB) as it offers empirical evidence on the decision usefulness of the disclosure under the revised IAS 1 (revised 2007) in an emerging market context.

The purpose of this study is to examine the decision usefulness, namely predictive power and value relevance of NI as compared to CI for financial firms listed in Malaysia. The study specifically aims to: 1) examine whether NI has more predictive power on future operating cash flows and future earnings when compared to $\mathrm{CI}, 2$ ) to examine whether NI is more value relevant than CI.

This paper consists of five sections: Section 1 introduces the study, Section 2 outlines the relevant literature review, Section 3 explains the methodology, Section 4 discusses the results and findings, and Section 5 concludes the paper.

\section{Literature Review}

\subsection{Agency Theory}

The agency theory prescribes two types of agency problem - Type I and Type II (Salvato \& Moores, 2010). Type I agency problems are induced when separation between ownership and control exists. In this context, managers have the incentive to serve their personal interests first, to the detriment of shareholders' wealth (Jensen \& Meckling, 1976). In 
contrast, Type II agency problems emerge when there is a conflict between controlling and non-controlling shareholders. Since controlling shareholders have the controlling power towards making economic and non-economic decisions, they may exercise their controlling powers to the extent that it can cause detrimental results to the non-controlling shareholders. This has been documented by past studies (Ali, Chen, \& Radhakrishnan, 2007; Villalonga \& Amit, 2006).

Type II agency problems tend to come from higher ownership concentration, thereby leading to agency problems where controlling shareholders have privileged access to gain informational advantage (Abdullah et al., 2015). Inevitably, this will reduce the demand for quality reporting deserved by external shareholders (Abdullah et al., 2015; Ball et al., 2003; Fan \& Wong, 2002). Moreover, the effectiveness of other corporate governance mechanisms (e.g., board independence and lack of CEO duality) may also be undermined by the strong influence exerted by the controlling shareholders (Bar-Yosef \& Prencipe, 2013). Therefore, external shareholders may relate the lower reporting quality to the high ownership concentration, particularly in the Malaysian setting, unlike developed countries where the ownership structures are dispersed.

\subsection{Conceptual Framework and Decision Usefulness of Accounting Information}

The IASB Conceptual Framework 2018 asserts that the main objective of financial reporting is "to provide financial information about the reporting entity that is useful to existing and potential investors, lenders and other creditors in making decisions relating to providing resources to the entity" (IASB, 2018). The accounting information is deemed to be "decision useful" when it is "relevant and faithfully represented". Information is deemed relevant and decision useful when it possesses predictive values, such that it can be used to help the financial statement users to predict future earnings and cash flows.

Additionally, the value relevance concept is also related to the decision usefulness concept. Research on value relevance involves examining the accounting information, and the equity market values. The accounting information is regarded as value relevant if it establishes a predictable relationship with share prices (Barth, Beaver, \& Landsman, 2001). The usefulness of the accounting information is measured by the reactions of the investors, which is captured in the share prices. 
The efficient market hypothesis (EMH) can be applied to describe the relationship between the accounting numbers and share prices. Malkiel and Fama (1970) stated that EMH can be in three (3) forms of efficiency: weak, semi-strong and strong. A market is regarded as a weak form if all past information was captured in share prices. In contrast, a market is regarded as a semi-strong form when the share prices captured all publicly available information. Finally, a market is deemed as a strong form if all public and private information had been fully captured in the share prices. Past studies (Cheah, 2005; Hussin, Ahmed \& Ying, 2010) have shown that the Malaysian market is in the semi-strong form where all publicly available information is captured in the share prices. The annual reports are one of the channels where firm information is released to the public. Therefore, any publicly available information (e.g., annual reports' information) should be captured in share prices if the information is regarded as relevant and decision useful to the investors.

\subsection{Predictive Power of NI and CI}

The predictive power of NI, in comparison to CI, has been inconclusive. For instance, using data from the US from 1994 to 1995, Dhaliwal et al. (1999) found that CI has no predicting power for future income. Using data from Germany, Pronobis and Zülch (2010) found that CI did not have better predictive power than NI. Goncharov and Hodgson (2011) also discovered that NI dominated CI in predicting cash flows while Kabir and Laswad (2011) noted that NI had a better predictive ability than CI. Contrary to this, other studies have found CI to carry more predictive power than NI. As an example, Choi, Das and Zang (2007) pointed out that $\mathrm{CI}$ has a better predictive ability than NI. Likewise, using data from Canada, Kanagaretnam et al. (2009) also noted that CI has better predictive power than NI on future operating cash flows whereas Bratten et al. (2016) disclosed that the adjustments for fair value for OCI were able to predict bank earnings.

The mixed and inconsistent findings of past studies suggest that certain factors, such as differences in the periods examined, differences in the sectors and countries as well as the use of different econometric models may be the reason causing the differences. The mixed results may also be due to the differences in institutional factors across various countries. For example, Europe (Goncharov \& Hodgson, 2011), Germany (Pronobis \& Zülch, 2010), the US (Bratten et al., 2016; Choi et al., 2007; Dhaliwal et al., 1999), New Zealand (Kabir \& Laswad, 2011), and Canada 
(Kanagaretnam et al., 2009). This has been observed by previous studies (Ball et al., 2003; Fan \& Wong, 2002; Holthausen, 2009; Leuz et al., 2003) which noted that this factor could affect the decision usefulness of the reported earnings.

Past studies had focused on different sectors, thereby contributing to the differences. For example, financial sectors (Bratten et al., 2016), non-financial sectors (Choi et al., 2007; Kanagaretnam et al., 2009; Pronobis \& Zülch, 2010), and mixed sectors ${ }^{5}$ (Dhaliwal et al., 1999; Goncharov \& Hodgson, 2011; Kabir \& Laswad, 2011). Moreover, the balance sheets of firms in the financial sector tend to be structurally different from firms in the non-financial sector. This is because majority of the assets for financial firms are likely made up of financial instrument assets (Barth et al., 2017; Duh et al., 2012) whereas for non-financial firms, their major assets are non-financial instrument assets. Previous findings on the $\mathrm{CI}$ for non-financial firms had not been able to provide empirical evidence, hence no comparison could be made. This study, therefore, undertakes to address the gap, by focusing on the predictive power of $\mathrm{NI}$ in comparison to $\mathrm{CI}$ for financial firms.

The inconsistent results of past studies do not seem helpful for establishing hypotheses as to whether NI or CI has more predictive powers. However, it is expected that NI would have more predictive powers than $\mathrm{CI}$ because financial instrument securities are likely to form a sizeable portion of the assets for financial firms (Barth et al., 2017). Due to the sizeable portion of financial instrument securities lying in the balance sheets of financial firms, these financial instruments of the OCI items (e.g., AFS, CFH, and NIH) would be subjected to higher exposures of the unrealised fair value changes. Past studies (Al-Yaseen \& Al-Khadash, 2011; Barth et al., 1995; Duh et al., 2012) have found that the recognition of unrealised fair value changes on financial instruments increased firms' earnings volatility. As such, these OCI items are likely to be more transitory and volatile in nature, thereby more exposed to higher measurement errors, and lower predictive powers. In this regard, the NI, which has lower transitory items, is expected to have higher predictive powers as compared to the $\mathrm{CI}$.

Based on the above, it is therefore hypothesised that:

$\mathrm{H}_{1 \mathrm{a}}$ : The NI has more predictive power than $\mathrm{CI}$ on future operating cash flows.

$\mathrm{H}_{1 \mathrm{~b}}$ : The NI has more predictive power than $\mathrm{CI}$ on future earnings.

${ }^{5}$ Mixed sectors consist of both financial and non-financial sectors 


\subsection{Value Relevance of NI and CI}

A review of past studies showed that the findings on the value relevance of NI in comparison to $\mathrm{CI}$, have been inconclusive. Some noted that NI was superior to CI (e.g. Mechelli \& Cimini, 2014; Campbell, 2015; Veltri \& Ferraro, 2018). Others revealed opposite results (e.g. Cahan, Courtenay, Gronnewoller, \& Upton, 2000; Chambers et al., 2007; Kanagaretnam et al., 2009). Researchers like Lin, Martinez, Wang and Yang (2018) found that investors only attach values to OCI if it was presented in the changes in equity statements.

As explained earlier, these mixed and inconclusive findings can be attributed to several factors such as differences in the periods examined, differences between countries and sectors used in the sample, and differences in terms of econometric models used. Given that the NI, which has less transitory items, would be superior to CI with regard to value relevance, it is therefore hypothesised that:

$\mathrm{H}_{2}$ : The NI is more value relevant than CI.

\section{Methodology}

This study employs secondary data that were derived from financial firms listed on Bursa Malaysia. As discussed earlier, financial instrument securities were likely to form a sizeable portion of the assets for financial firms (Barth et al., 2017). Due to the sizeable portion of financial instrument securities lying in the balance sheets of the financial firms, these financial instruments of the OCI items (e.g., AFS, CFH and NIH) would be subjected to higher unrealised fair value changes of the financial instruments.

The yearly data of the NI and CI were manually collected from annual reports. These data on stock prices were obtained from DataStream. Other data on shares outstanding and book value of equity were also manually extracted from annual reports. Data for this study were generated from the consolidated figures (Ball, 2006). The statement of comprehensive income, which was required under the IAS 1 (Revised 2007) had become effective in Malaysia in 2012. Based on this, the period of analysis was thus selected from 2012 to 2017. Elimination was made for unsuitable firms (e.g., firms with no OCI items, firms classified under PN 17 or financially distressed firms). The Mahalanobis distance test was used to identify and eliminate the outliers. 


\subsection{Predictive Power Test}

The following models, which were based on the models used by Dechow (1994), Goncharov and Hodgson (2011), and Pronobis and Zülch (2010), were applied for comparing the predictive power of NI and CI. The adjusted R-squared of model 1 was compared with model 2 to reflect the predictive power on future cash flows from operations (CFO), and with model 3 and model 4 to reflect the predictive power on future earnings. The significance in the adjusted R-squared's difference between the two non-nested models (e.g., between models 1 and 2 and models 3 and 4) was tested using Vuong's (1989) test. This is to validate whether one model was significantly better than the other. Except for the control variables, all other variables were deflated by the average total assets so as to minimise the heteroscedasticity problem (Goncharov \& Hodgson, 2011; Kanagaretnam et al., 2009). Control variables (e.g., size and leverage) were included as they were expected to influence the predictive power of the reported earnings. As for firm size, the reported earnings of larger firms were expected to impact on the predictive power as these firms were subjected to close examinations by financial analysts and investors (Al-dhamari \& Ku Ismail, 2013). The leverage of firms was also expected to impact on the predictive power of reported earnings as "income-increasing earnings management" methods were possibly employed by firms to avoid violation of debt covenant (Al-dhamari \& $\mathrm{Ku}$ Ismail, 2013; Zhong, Chourou, \& Ni, 2017). As for measurements, the natural log of book value of total assets was used to depict firm size (SIZE) whereas the leverage (DTE) was determined by the proportion of total debt to total equity (Acaranupong, 2017; Hassan, Mohd-Saleh, Rahman, \& Shukor, 2016).

$$
\begin{aligned}
& \text { CFO_A } A_{j t+1}=a_{0}+a_{1} N_{-} A_{j t}+a_{2} S_{Z Z E}+a_{3} D_{j t} E_{j t}+\varepsilon_{j t} \\
& \text { CFO_A } A_{j t+1}=a_{0}+a_{1} C I \_A_{j t}+a_{2} S_{Z} E_{j t}+a_{3} D_{T E}+\varepsilon_{j t} \\
& \text { NI_A } \mathrm{j}_{\mathrm{jt}+1}=\mathrm{a}_{0}+\mathrm{a}_{1} \mathrm{NI}_{2} \mathrm{~A}_{\mathrm{jt}}+\mathrm{a}_{2} \mathrm{SIZE}_{\mathrm{jt}}+\mathrm{a}_{3} \mathrm{DTE}_{\mathrm{jt}}+\varepsilon_{\mathrm{jt}} \\
& \text { NI_A } A_{j t+1}=a_{0}+a_{1} C I \_A_{j t}+a_{2} S_{Z} E_{j t}+a_{3} D_{T E}+\varepsilon_{j t}
\end{aligned}
$$

where,

$$
\begin{aligned}
\text { CFO_A }_{j t+1}= & \text { Cash flow from operations for firm } j \text { in year } t+1, \\
& \text { deflated by average total assets; } \\
\text { NI_A } A_{j t+1}= & \text { Net income for firm } j \text { in year } t+1 \text {, deflated by average } \\
& \text { total assets; } \\
\text { NI_A } A_{j t}= & \begin{array}{l}
\text { Net income for firm } j \text { in year } t \text {, deflated by average } \\
\text { total assets; }
\end{array}
\end{aligned}
$$




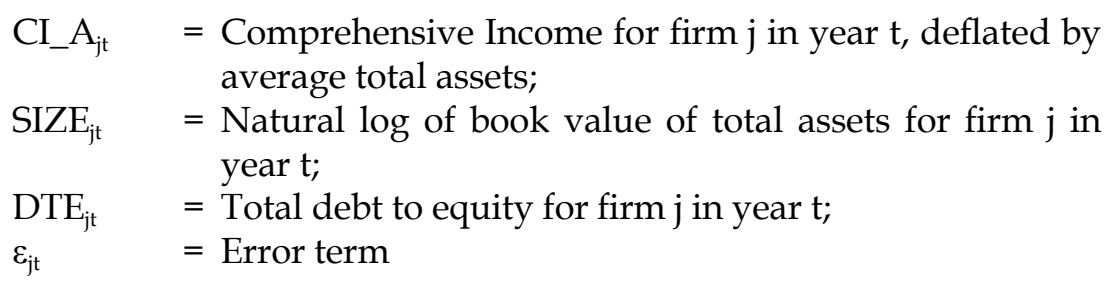

\subsection{Value Relevance Test}

\subsubsection{Price Model}

In comparing the value relevance of $\mathrm{CI}$ to NI, the price model (Kabir \& Laswad, 2011; Kanagaretnam et al., 2009; Mechelli \& Cimini, 2014) which was based on the Ohlson (1995) model, was applied to compare the adjusted R-squared between Equation 5 and Equation 6 below. The significance in the adjusted R-squared's difference of the two models was tested with Vuong's (1989) test. The number of outstanding shares was used to deflate all the variables (except control variables) in order to reduce the heteroscedasticity problem (Kanagaretnam et al., 2009; Veltri \& Ferraro, 2018). As for value relevance studies, firm size and leverage were incorporated as controlled variables as they were commonly used in past studies (Acaranupong, 2017; Ahmad, Hassan, \& Jaffar, 2016).

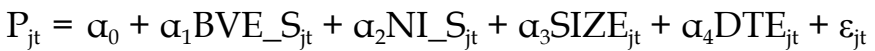

$$
\begin{aligned}
& P_{j \mathrm{t}}=\mathrm{a}_{0}+\mathrm{a}_{1} \mathrm{BVE}_{-} \mathrm{S}_{\mathrm{jt}}+\mathrm{a}_{2} \mathrm{CI} \_\mathrm{S}_{\mathrm{jt}}+\mathrm{a}_{3} \mathrm{SIZE}_{\mathrm{jt}}+\mathrm{a}_{4} \mathrm{DTE}_{\mathrm{jt}}+\varepsilon_{\mathrm{jt}}
\end{aligned}
$$

where,

$$
\begin{array}{ll}
\mathrm{P}_{\mathrm{jt}} & =\text { Adjusted price per share for firm } \mathrm{j} \text { ending after } 4 \text { months } \\
& \text { from financial year-end for year } \mathrm{t} ; \\
\text { NI_S } \mathrm{S}_{\mathrm{jt}}= & \text { Net income per share for firm } \mathrm{j} \text { in year } \mathrm{t} ; \\
\text { CI_S } & =\text { Comprehensive income per share for firm } \mathrm{j} \text { in year } \mathrm{t} ; \\
\text { BVE_S } & =\text { Book value of equity per share for firm } \mathrm{j} \text { in year } \mathrm{t} ; \\
\text { SIZE }_{\mathrm{jt}}= & \text { Natural log of book value of total assets for firm } \mathrm{j} \text { in year } \\
& \mathrm{t} ; \\
\mathrm{DTE}_{\mathrm{jt}}= & \text { Total debt to equity for firm } \mathrm{j} \text { in year } \mathrm{t} ; \\
\varepsilon_{\mathrm{jt}} & =\text { Error term }
\end{array}
$$

The adjusted prices were obtained from the DataStream databases. These prices had been adjusted for dividends, stock consolidations, stock splits, rights issues, and bonus issues. This helped to ensure that the prices were always comparable across different periods (Ball et al., 
2000, 2003; Kanagaretnam et al., 2009; Kothari \& Zimmerman, 1995). As the deadline for the filing of annual reports for all firms listed in Bursa Malaysia falls on the fourth month after the financial year-end ("FYE"), the market price at the end of the fourth month after the FYE was used. This is to ensure that investors have access and, can therefore, react to all the available information contained in the annual reports (Chen, Chen, \& Su, 2001; Easton \& Zhang, 2017; Elshandidy, 2014; Kanagaretnam et al., 2009).

\subsubsection{Return Model}

In order to add robustness to the results, an additional value relevance test was performed by using the return model (Kanagaretnam et al., 2009; Kothari \& Zimmerman, 1995; Mechelli \& Cimini, 2014). The reason is that both the price and return models have their merits and demerits although the price model carries less bias in the estimated earnings coefficients. Nonetheless, the price model is subjected to more scaling and heteroscedasticity problems. In comparison, the return model has less heteroscedasticity problems although it may be more biased in the estimated earnings coefficients than the price model. Additionally, the price and return models focus on different perspectives of the value relevance. The price model focusses on the valuation perspective whilst the return model focusses on the information perspective where it measures the arrival of information over a period of time (Goncharov \& Hodgson, 2011). According to Kothari and Zimmerman (1995), using both models would offer more convincing evidence.

For the purpose of performing the robustness tests, the return model was used (Chambers et al., 2007; Dhaliwal et al., 1999; Kabir \& Laswad, 2011; Kanagaretnam et al., 2009), particularly the model that was derived from Kothari and Zimmerman (1995). This was utilised by comparing the adjusted R-squared between Equation 7 and Equation 8 below. The significance in the adjusted R-squared difference of the two models was then tested using Vuong's (1989) test.

$$
\begin{aligned}
& \operatorname{RET}_{\mathrm{jt}}=\mathrm{a}_{0}+\mathrm{a}_{1} \mathrm{NI}_{1} \mathrm{M}_{\mathrm{jt}}+\mathrm{a}_{2} \mathrm{SIZE}_{\mathrm{jt}}+\mathrm{a}_{3} \mathrm{DTE}_{\mathrm{jt}}+\varepsilon_{\mathrm{jt}} \\
& \operatorname{RET}_{\mathrm{jt}}=\mathrm{a}_{0}+\mathrm{a}_{1} \mathrm{CI}_{-} \mathrm{M}_{\mathrm{jt}}+\mathrm{a}_{2} \mathrm{SIZE}_{\mathrm{jt}}+\mathrm{a}_{3} \mathrm{DTE}_{\mathrm{jt}}+\varepsilon_{\mathrm{jt}}
\end{aligned}
$$

where,

$$
\begin{aligned}
\operatorname{RET}_{\mathrm{jt}}= & \text { Annual share returns for firm } \mathrm{j} \text { commencing from } 8 \\
& \text { months before and ending } 4 \text { months after the financial } \\
& \text { year-end } \mathrm{t} ;
\end{aligned}
$$


NI_ $M_{j t}=$ Net Income for firm $j$ in year $t$, deflated by equity's market value at the beginning of the year;

CI_M $\mathrm{M}_{\mathrm{jt}}=$ Comprehensive Income for firm $\mathrm{j}$ in year $\mathrm{t}$, deflated by equity's market value at the beginning of the year;

$\mathrm{SIZE}_{\mathrm{jt}}=$ Natural log of book value of total assets for firm $\mathrm{j}$ in year $\mathrm{t}$;

$\mathrm{DTE}_{\mathrm{jt}}=$ Total debt to equity for firm $\mathrm{j}$ in year $\mathrm{t}$;

$\varepsilon_{\mathrm{jt}} \quad=$ Error term

\section{Results and Findings}

The initial population size comprised 31 financial firms that were listed on Bursa Malaysia as of 31 December 2017. Out of this, elimination of firms was made for firms that were found not suitable (e.g., firm with no OCI items and financially distress firm) as exhibited in Table 1 below:

Table 1: Elimination of Sample Data

\begin{tabular}{lc}
\hline Criteria & No. of firms \\
\hline All firms listed in the financial sector & 31 \\
Less & \\
Firm with no OCI items & 1 \\
Financially distressed firm & 1 \\
\hline Final sample & 29 \\
\hline
\end{tabular}

Following screening, the final sample came to 29 firms (Appendix 1), consisting of an unbalanced panel of 164 firm-year observations. With regards to the predictive power for models 1 to 4 , six firm-year observations were removed because they were considered as outliers. Here, the Mahalanobis distance test was used. Following this, an unbalanced panel data of 158 firm-observations were available for testing. The value relevance test for models 5 and 6 was made using price model. This led to eight firm-year observations being removed which were considered as outliers. This left an unbalanced panel data of 156 firm-observations for testing.

In relation to the value relevance test, the return model was applied for models 7 and 8 . Due to the parameters used which included the earnings' change from $t-1$ to $t$, a total of 4 firm-years' observations were dropped due to data unavailability. Based on the Mahalanobis distance 
test, a total of 9 firm-year observations were further excluded as outliers. Consequently, only the remaining unbalanced panel data of 151 firmyears' observations were available for testing models 7 and 8 .

The descriptive statistics are illustrated in Table 2. It is noted that the mean values of the earnings' variables (NI_A and CI_A) were greater than zero. This implies that, on average, the sample firms, over the six-year period of 2012 to 2017, were profitable. It is further noted that the mean values for CI_A (0.027), CI_S (0.484), and CI_M (0.112) were higher than the mean values for NI_A (0.026) and NI_S (0.467), and NI_M (0.107), respectively. This shows that, on average, the OCI items have positive mean values. The standard deviations for CI_A (0.030), CI_S (0.513), and CI_M (0.087) were also higher than NI_A (0.029), NI_S (0.488), and NI_M (0.086). This indicates that CI was more volatile than NI.

With regards to ownership structure, the compilation based on annual reports from 2014 to 2017 showed that the total average of the top three shareholdings for the sampled financial firms in Malaysia was about 58 per cent (untabulated). This confirms that the ownership structure in Malaysia was highly concentrated (Claessens et al., 2000; Haniffa \& Hudaib, 2006; Maigoshi et al., 2018).

\subsection{Correlation Matrices}

Table 3 exhibits the correlation matrices for models 1 to 8. Panel A depicts the correlation matrix for models 1 to 4 . It should be noted that the highest correlation of 0.937 was between NI_A and CI_A. This is not unexpected as NI_A was nested upon CI_A. However, these two variables never appeared in the same model for regression analysis. Therefore, after discarding this, the highest number was 0.820 , which was below the threshold of 0.900 . Hence, multicollinearity was not a serious concern for models 1 to 4 . The same applies to the findings noted in Panels B and C. High correlations were observed between NI_S and CI_S (0.977), and between NI_M and CI_M (0.949), respectively. After discarding these, the highest correlations were 0.872 and 0.804, respectively. Hence, no serious multicollinearity problems exist for models 5 to 8 .

This study uses the panel data analysis technique which carries several advantages. Firstly, panel data tend to be more comprehensive, accurate, dynamic, informative and better at deducing relationships which cannot be deduced through cross-sectional and time-series data 
Table 2: Descriptive Statistics

\begin{tabular}{lccccc}
\hline Variable & $\begin{array}{c}\text { No. of } \\
\text { Observations }\end{array}$ & Mean & $\begin{array}{c}\text { Standard } \\
\text { Deviation }\end{array}$ & Min & Max \\
\hline
\end{tabular}

Panel A: Variables for Predictive Power (Models 1 to 4)

\begin{tabular}{llrrrr} 
CFO_A $_{(t+1)}$ & 158 & 0.016 & 0.061 & $(0.180)$ & 0.227 \\
NI_A $_{(t+1)}$ & 158 & 0.031 & 0.031 & $(0.037)$ & 0.167 \\
NI_A $_{t}$ & 158 & 0.026 & 0.029 & $(0.045)$ & 0.120 \\
CI_A & 158 & 0.027 & 0.030 & $(0.043)$ & 0.133 \\
SIZE $_{t}$ & 158 & 16.426 & 2.181 & 12.667 & 20.456 \\
DTE $_{t}$ & 158 & 6.214 & 4.575 & 0.011 & 18.793 \\
\hline
\end{tabular}

Panel B: Variables for Price Model (Models 5 to 6)

\begin{tabular}{llrrrr}
$P_{t}$ & 156 & 5.283 & 5.068 & 0.071 & 19.960 \\
BVE_S $_{t}$ & 156 & 3.708 & 3.013 & 0.317 & 14.524 \\
NI_S $_{t}$ & 156 & 0.467 & 0.488 & $(0.182)$ & 2.403 \\
CI_S $_{\mathrm{t}}$ & 156 & 0.484 & 0.513 & $(0.159)$ & 2.456 \\
SIZE $_{\mathrm{t}}$ & 156 & 16.345 & 2.208 & 11.892 & 20.456 \\
DTE $_{\mathrm{t}}$ & 156 & 6.192 & 4.726 & 0.011 & 19.892 \\
\hline
\end{tabular}

Panel C: Variables for Price Model (Models 7 to 8)

$\begin{array}{llrrrr}\text { RET }_{\mathrm{t}} & 151 & 1.082 & 0.269 & 0.500 & 2.365 \\ \text { NI_M }_{\mathrm{t}} & 151 & 0.107 & 0.086 & (0.244) & 0.461 \\ \text { CI_M }_{\mathrm{t}} & 151 & 0.112 & 0.087 & (0.262) & 0.461 \\ \text { SIZE }_{\mathrm{t}} & 151 & 16.539 & 2.167 & 12.667 & 20.456 \\ \text { DTE }_{\mathrm{t}} & 151 & 6.554 & 4.664 & 0.015 & 19.892\end{array}$

Notes:

CFO_A $A_{t+1}=$ Cash flow from operation in year $t+1$, deflated by average total assets

NI_A $\mathrm{t}_{t+1}=$ Net income in year $\mathrm{t}+1$, deflated by average total assets

NI_A $A_{t} \quad=$ Net income in year $t$, deflated by average total assets

CI_A $A_{t}=$ Comprehensive income in year $t$, deflated by average total assets

$\mathrm{P}_{\mathrm{t}} \quad=$ Adjusted market price per share ending after 4 months from FYE for year $\mathrm{t}$

BVE_S $S_{t}=$ Book value of equity per share in year $t$

NI_S $S_{t}=$ Net income per share in year $t$

CI_S $\quad=$ Comprehensive income per share in year $\mathrm{t}$

$\mathrm{SIZE}_{\mathrm{t}} \quad=$ Natural log of book value of total assets in year $\mathrm{t}$

DTE $_{\mathrm{t}}=$ Total debt to equity in year $\mathrm{t}$

$\mathrm{RET}_{\mathrm{t}}=$ Annual share return commencing from 8 months before and 4 months after the FYE

NI_M $M_{t} \quad=$ Net income in year $\mathrm{t}$, deflated by beginning market equity

CI_M $\mathrm{M}_{\mathrm{t}}=$ Comprehensive income in year $\mathrm{t}$, deflated by beginning market equity 
Table 3: Correlation Matrices for Models 1 to 8

Panel A: Correlation Matrix for Variables in Models 1 to 4

\begin{tabular}{lccllll}
\hline & CFO_A $_{(t+1)}$ & NI_A A $_{(t+1)}$ & NI_A $_{t}$ & CI_A $_{t}$ & SIZE $_{t}$ & DTE $_{t}$ \\
\hline CFO_A $_{(t+1)}$ & 1.000 & & & & & \\
NI_AA $_{(t+1)}$ & 0.144 & 1.000 & & & & \\
NI_A $_{t}$ & $0.229^{*}$ & $0.778^{* *}$ & 1.000 & & & \\
CI_A $_{t}$ & $0.288^{* *}$ & $0.753^{* *}$ & $0.937^{* *}$ & 1.000 & & \\
SIZE $_{t}$ & $(0.151)$ & $(0.463)^{* * *}$ & $(0.434)^{* *}$ & $(0.418)^{* *}$ & 1.000 & \\
DTE $_{t}$ & $(0.137)$ & $(0.538)^{* *}$ & $(0.516)^{* *}$ & $(0.508)^{* *}$ & $0.820^{* *}$ & 1.000
\end{tabular}

Panel B: Correlation Matrix for Variables in Models 5 and 6

\begin{tabular}{|c|c|c|c|c|c|c|}
\hline & $P_{t}$ & BVE_S $S_{t}$ & NI_S & CI_S & $\mathrm{SIZE}_{\mathrm{t}}$ & DTE $_{1}$ \\
\hline$P_{t}$ & 1.000 & & & & & \\
\hline BVE_S $S_{t}$ & $0.766^{* *}$ & 1.000 & & & & \\
\hline NI_S & $0.867^{* *}$ & $0.868^{* *}$ & 1.000 & & & \\
\hline CI_S $S_{t}$ & $0.853^{* *}$ & $0.872^{* *}$ & $0.977^{* *}$ & 1.000 & & \\
\hline $\mathrm{SIZE}_{\mathrm{t}}$ & $0.564^{* *}$ & $0.585^{* *}$ & $0.517^{* *}$ & $0.509^{* *}$ & 1.000 & \\
\hline DTE $_{t}$ & $0.429^{* *}$ & $0.366^{* *}$ & $0.435^{* *}$ & $0.421^{* *}$ & $0.810^{* *}$ & 1.000 \\
\hline \multicolumn{7}{|c|}{ Panel C: Correlation Matrix for Variables in Models 7 and 8} \\
\hline & \multicolumn{2}{|c|}{$\mathrm{RET}_{\mathrm{t}}$} & NI_M & CI_M $\mathrm{M}_{\mathrm{t}}$ & $\mathrm{SIZE}_{\mathrm{t}}$ & DTE \\
\hline $\mathrm{RET}_{\mathrm{t}}$ & \multicolumn{2}{|c|}{1.000} & & & & \\
\hline NI_M & \multicolumn{2}{|c|}{$0.443^{* *}$} & 1.000 & & & \\
\hline CI_Mt & \multicolumn{2}{|c|}{$0.414^{\star *}$} & $0.949^{* *}$ & 1.000 & & \\
\hline $\mathrm{SIZE}_{\mathrm{t}}$ & \multicolumn{2}{|c|}{$(0.116)$} & $(0.011)$ & $(0.044)$ & 1.000 & \\
\hline DTE $_{t}$ & \multicolumn{2}{|c|}{$(0.039)$} & $(0.008)$ & $(0.040)$ & $0.804^{* *}$ & 1.000 \\
\hline
\end{tabular}

Note: * and ** represent significance at 0.05 and 0.01 levels.

(Baltagi, 2008). Secondly, panel data could enrich the empirical analysis, which cannot be attained from using time-series and cross-sectional data (Gujarati, 2009). Additionally, the potential effect of unobserved heterogeneity across firms can be controlled by using common estimation techniques such as fixed effects and random effects (Gujarati, 2009).

For fixed effects models, the heteroscedasticity problems, if any, are corrected using White-corrected standard errors or robust standard errors. However, if they contained both the heteroscedasticity and autocorrelation problems, they are corrected using Driscoll-Kraay corrected standard errors. 


\subsection{Empirical Results}

\subsubsection{Predictive Power Test}

\section{Predictive Power and Future CFO}

Table 4 exhibits the predictive power of NI_A and CI_A using fixed effects models (with $p$ values in parentheses) since the $p$ values of the Hausman test for both models were significant at the 0.05 levels. The coefficients of NI_A and CI_A were 0.115 and 0.623 , respectively. The coefficient for NI_A was not significant at the 0.10 level, whereas the coefficient for CI_A was significant at 0.05 level. The coefficients of SIZE for both models were positive and significant at 0.01 level. This implies that larger firms tend to be more capable of generating higher future CFO_A than smaller firms. However, the coefficients of DTE for both models were insignificant at the conventional levels. The adjusted R-squared for models 1 and 2 were 0.2958 and 0.3204, respectively. However, the Vuong z-statistics showed that the adjusted R-squared's difference is insignificant at the 0.10 level. Therefore, the hypothesis of $\mathrm{H}_{1 \mathrm{a}}$ is not supported. These results are in line with Goncharov and

Table 4: Predictive Power Models to Predict Future CFO (Fixed Effects Models)

\begin{tabular}{|c|c|c|}
\hline $\begin{array}{l}\text { Independent } \\
\text { Variables }\end{array}$ & $\begin{array}{c}C F A_{-} A_{j t+1}=a_{0}+a_{1} N I \_A_{j t}+ \\
a_{2} S_{Z E} E_{j t}+a_{3} D T E_{j t}+\varepsilon_{j t} \\
(\text { Model 1) }\end{array}$ & $\begin{array}{c}\text { CFO_A } A_{j t+1}=a_{0}+a_{1} C I \_A_{j t}+ \\
a_{2} S I Z E_{j t}+a_{3} D T E_{j t}+\varepsilon_{j t} \\
(\text { Model 2) }\end{array}$ \\
\hline Constant & $-0.753(0.000)^{* * *}$ & $-0.765(0.000)^{* * *}$ \\
\hline NI_A & $0.115(0.657)$ & \\
\hline CI_A & & $0.623(0.022)^{* *}$ \\
\hline SIZE & $0.047(0.000)^{* * *}$ & $0.047(0.000)^{* * *}$ \\
\hline DTE & $0.000(0.907)$ & $0.000(0.910)$ \\
\hline F-statistic & $3.127(0.000)^{* * *}$ & $3.387(0.000)^{* * *}$ \\
\hline Adjusted $\mathrm{R}^{2}$ & 0.2958 & 0.3204 \\
\hline Vuong z-statistic & & $-0.974(0.331)$ \\
\hline $\begin{array}{l}\text { Hausman test } \\
\text { Chi-square }\end{array}$ & $8.783(0.032)$ & $8.750(0.033)$ \\
\hline Model & Fixed Effects & Fixed Effects \\
\hline No. of observations & 158 & 158 \\
\hline
\end{tabular}

Note: * ** and ${ }^{* * *}$ represent significance at $0.10,0.05$ and 0.01 levels; the standard errors have been reported using Driscoll-Kraay standard errors. 
Hodgson (2011), and Pronobis and Zülch (2010) in that CI did not enhance the predictive power on future cash flows.

\section{Predictive Power and Future NI}

Table 5 exhibits the predictive power of NI_A and CI_A, using fixed effects models (with $\mathrm{p}$ values in parentheses). Fixed effects models were used since the $p$ values of the Hausman test for both models were significant at conventional levels. The coefficients of NI_A and CI_A were 0.052 and 0.005 , respectively, also insignificant at 0.10 level. The coefficients of SIZE for both models were negative and significant at 0.01 level. The coefficients of DTE for both models were also negative and significant at 0.10 level. This suggests that larger and higher leveraged firms tend to generate lower future NI_A. The adjusted R-squared for models 3 and 4 were 0.7654 and 0.7650 , respectively. This indicates that the predictive power of NI_A was slightly greater than the CI_A on future earnings. However, the Vuong z-statistics showed that the adjusted R-squared difference was not significant at the 0.10 level. Therefore, the hypothesis of $\mathrm{H}_{1 \mathrm{~b}}$ is not supported. Even though $\mathrm{H}_{1 \mathrm{~b}}$ is not

Table 5: Predictive Power Models to Predict Future NI (Fixed Effects Models)

\begin{tabular}{|c|c|c|}
\hline $\begin{array}{l}\text { Independent } \\
\text { Variables }\end{array}$ & $\begin{array}{c}\text { NI_A } A_{j t+1}=a_{0}+a_{1} N I \_A_{j t}+ \\
a_{2} S_{Z} E_{j t}+a_{3} D T E_{j t}+\varepsilon_{j t} \\
(\text { Model 3) }\end{array}$ & $\begin{array}{c}\text { NI_A } A_{j t+1}=a_{0}+a_{1} C I \_A_{j t}+ \\
a_{2} S_{Z} E_{j t}+a_{3} D E_{j t}+\varepsilon_{j t} \\
(\text { Model } 4)\end{array}$ \\
\hline Constant & $0.488(0.003)^{* * *}$ & $0.487(0.001)^{* * *}$ \\
\hline NI_A & $0.052(0.731)$ & \\
\hline CI_A & & $0.005(0.945)$ \\
\hline SIZE & $-0.028(0.002)^{* * *}$ & $-0.028(0.002)^{* * *}$ \\
\hline DTE & $-0.001(0.063)^{*}$ & $-0.001(0.056)^{*}$ \\
\hline F-statistic & $17.526(0.000)^{\star \star *}$ & $17.484(0.000)^{\star * *}$ \\
\hline Adjusted $\mathrm{R}^{2}$ & 0.7654 & 0.7650 \\
\hline Vuong z-statistic & $0.194(0.846)$ & \\
\hline $\begin{array}{l}\text { Hausman test } \\
\text { Chi-square }\end{array}$ & $97.595(0.000)^{* * *}$ & $103.994(0.000)^{* * *}$ \\
\hline Model & Fixed Effects & Fixed Effects \\
\hline No. of observations & 158 & 158 \\
\hline
\end{tabular}

Note: ${ }^{*}, * *$ and ${ }^{* *}$ represent significance at $0.10,0.05$ and 0.01 levels; the standard errors have been reported using Driscoll-Kraay standard errors. 
supported, the results indicate that the CI, which is transitory in nature, did not improve the predictive power of NI. This outcome is consistent with Goncharov and Hodgson (2011) and Pronobis and Zülch (2010).

\subsubsection{Value Relevance Test Using Price Models}

Table 6 shows the value relevance of NI and CI, using fixed effects models (with $p$ values in parentheses). Fixed effects models were used since the $p$ values of the Hausman test for both models were significant at conventional levels. The coefficients of BVE_S for models 5 and 6 were 0.227 and 0.494 , respectively, also significant at the 0.05 and 0.01 levels. The coefficients of NI_S and CI_S were 5.236 and 1.623, respectively, also significant at 0.01 level. This suggests that share prices were positively and significantly related to BVE_S, NI_S, and CI_S. This finding is within expectation. The adjusted R-squared for models 5 and 6 were 0.9528 and 0.9342 , respectively. The coefficients of SIZE were not significant for both models at the conventional level. However, the coefficients of DTE for models 5 and 6 were negatively correlated, but significant at the 0.05

Table 6: Value Relevance Models using Price Models (Fixed Effects Models)

\begin{tabular}{lcc}
\hline $\begin{array}{l}\text { Independent } \\
\text { Variables }\end{array}$ & $\begin{array}{c}\mathrm{P}_{\mathrm{jt}}=\mathrm{a}_{0}+\mathrm{a}_{1} \mathrm{BVE}_{-} \mathrm{S}_{\mathrm{jt}}+ \\
\mathrm{a}_{2} \mathrm{NI}_{2} \mathrm{~S}_{\mathrm{jt}}+\mathrm{a}_{3} \mathrm{SIZE}_{\mathrm{jt}}+ \\
\mathrm{a}_{4} \mathrm{DTE} \mathrm{E}_{\mathrm{jt}}+\varepsilon_{\mathrm{jt}}(\mathrm{Model} 5)\end{array}$ & $\begin{array}{c}\mathrm{P}_{\mathrm{jt}}=\mathrm{a}_{0}+\mathrm{a}_{1} \mathrm{BVE} \mathrm{S}_{\mathrm{jt}}+ \\
\mathrm{a}_{2} \mathrm{CI}_{2} \mathrm{~S}_{\mathrm{jt}}+\mathrm{a}_{3} \mathrm{SIZE}_{\mathrm{jt}}+ \\
\mathrm{a}_{4} \mathrm{DTE}_{\mathrm{jt}}+\varepsilon_{\mathrm{jt}}(\mathrm{Model} 6)\end{array}$ \\
\hline Constant & $0.126(0.953)$ & $1.616(0.514)$ \\
BVE_S & $0.227(0.042)^{* *}$ & $0.494(0.000)^{* * *}$ \\
NI_S & $5.236(0.001)^{* * *}$ & $1.623(0.007)^{* * *}$ \\
CI_S & $0.146(0.249)$ & $0.048(0.722)$ \\
SIZE & $-0.090(0.036)^{* *}$ & $-0.042(0.000)^{* * *}$ \\
DTE & $98.690(0.000)^{* * *}$ & $72.582(0.000)^{* * *}$ \\
\hline F-statistic & 0.9528 & 0.9342 \\
Adjusted R & $3.901(0.002)^{* * *}$ & $19.182(0.000)^{* * *}$ \\
Vuong Z-statistic & $11.813(0.019)^{* *}$ & \\
Hausman test & & Fixed Effects \\
Chi-square & 156 & 156 \\
\hline Model & Fixed Effects & \\
No. of observations & 156 &
\end{tabular}

Note: ${ }^{*}, * *$ and ${ }^{* * *}$ represent significance at $0.10,0.05$ and 0.01 levels; the standard errors have been reported using Driscoll-Kraay Standard Errors. 
and 0.01 levels. This indicates that higher leverage firms may result in lower share prices since higher leverage firms were perceived to be more risky by investors. The results for DTE were consistent with past studies (Acaranupong, 2017; Hassan et al., 2016). The Vuong z-statistics showed that the adjusted R-squared difference was significant at the 0.01 level, which is in favour of NI_S. Therefore, the hypothesis of $\mathrm{H}_{2}$ was strongly supported. With respect to value relevance, this implies that NI_S is better than CI_S, using price models. These findings are in line with Dhaliwal et al. (1999), Goncharov and Hodgson (2011), Mechelli and Cimini (2014), and Veltri and Ferraro (2018). However, it is not in line with Kanagaretnam et al. (2009) and Cahan et al. (2000).

\subsubsection{Additional Value Relevance Test Using Return Models}

The results for the value relevance test using return models are illustrated in Table 7 (with p values in parentheses). Fixed effects models were used since the $p$ values of the Hausman test for both models were significant at the conventional level. The coefficients of NI_M (2.168)

Table 7: Value Relevance Models Using Return Models (Fixed Effects Models)

\begin{tabular}{|c|c|c|}
\hline $\begin{array}{l}\text { Independent } \\
\text { Variables }\end{array}$ & $\begin{array}{c}\operatorname{RET}_{\mathrm{jt}}=\mathrm{a}_{0}+\mathrm{a}_{1} \mathrm{NI}_{1} \mathrm{M}_{\mathrm{jt}}+ \\
\mathrm{a}_{2} \mathrm{SIZE}_{\mathrm{jt}}+\mathrm{a}_{3} \mathrm{DTE}_{\mathrm{jt}}+\varepsilon_{\mathrm{jt}} \\
(\text { Model 7) }\end{array}$ & $\begin{array}{c}\mathrm{RET}_{\mathrm{jt}}=\mathrm{a}_{0}+\mathrm{a}_{1} \mathrm{CI} \mathrm{M}_{\mathrm{jt}}+ \\
\mathrm{a}_{2} \mathrm{SIZE}_{\mathrm{jt}}+\mathrm{a}_{3} \mathrm{DTE}_{\mathrm{jt}}+\varepsilon_{\mathrm{jt}} \\
(\text { Model } 8)\end{array}$ \\
\hline Constant & $5.142(0.001)^{\star * *}$ & $5.281(0.000)^{* * *}$ \\
\hline NI_M & $2.168(0.000)^{* * *}$ & \\
\hline CI_M & & $1.723(0.000)^{* * *}$ \\
\hline SIZE & $-0.255(0.005)^{* * *}$ & $-0.263(0.003)^{* * *}$ \\
\hline DTE & $-0.012(0.237)$ & $-0.007(0.535)$ \\
\hline F-statistic & $3.085(0.000)^{* * *}$ & $2.517(0.000)^{* * *}$ \\
\hline Adjusted $\mathrm{R}^{2}$ & 0.2872 & 0.2268 \\
\hline Vuong z-statistic & $2.154(0.033)^{\star *}$ & \\
\hline $\begin{array}{l}\text { Hausman test } \\
\text { Chi-square }\end{array}$ & $15.562(0.001)^{\star * *}$ & $10.316(0.016)^{* *}$ \\
\hline Model & Fixed Effects & Fixed Effects \\
\hline No. of observations & 151 & 151 \\
\hline
\end{tabular}

Note: ${ }^{*},{ }^{* *}$ and ${ }^{* * *}$ represent significance at $0.10,0.05$ and 0.01 levels; the standard errors have been reported using Driscoll-Kraay Standard Errors. 
and CI_M (1.723) were significant at the 0.01 level. The coefficients of SIZE for both models were negative and significant at 0.01 level. This implies that larger firms were likely to experience lower share returns as compared to smaller firms. Such an occurrence may suggest that larger firms have lower risks, therefore, investors would demand lower returns. The coefficients of DTE for models 7 and 8 were not significant at the conventional level. The adjusted R-squared for model 7 (0.2872) was higher than model 8 (0.2268). The Vuong test with a p-value of 0.033 showed that the adjusted R-squared difference was significant at 0.05 level. This is in favour of NI, thereby indicating that with respect to value relevance, NI_M was better than CI_M, using return models. The results, using the return models, are consistent with the price models. Overall, the results were consistent with Dhaliwal et al. (1999), Goncharov and Hodgson (2011), Mechelli and Cimini (2014), and Veltri and Ferraro (2018). However, it is not in line with Kanagaretnam et al. (2009) and Cahan et al. (2000).

\subsubsection{Robustness and Sensitivity Tests}

Sensitivity tests were undertaken for verifying the robustness of the results of the primary predictive power models, using a different deflator. Here, the regression for models 1 to 4 was rerun using the book value of equity as deflator instead of total assets. The purpose was to test whether the choice of deflator influenced the results (Bratten et al., 2016). The regression analysis output exhibited a substantially similar outcome as reported earlier, under the main models which had employed total assets as the deflator. As such, the results thus confirmed the findings of the main predictive power models (results are untabulated).

Sensitivity tests were also conducted for the value relevance test so as to confirm the robustness of the results obtained from the main price and return models, under different periods of time (Veltri \& Ferraro, 2018). Here, the regression was rerun by using two months after the FYE's share prices. This is because firms listed on the Bursa Malaysia were obligated to announce their unaudited financial results two months after the FYE. As such, investors may have reacted to the information announced via the quarterly announcement of the firms' unaudited financial results. The results of the regression analysis revealed that they were substantially unchanged. The results, therefore, confirmed the findings of the main price and return models (results are untabulated). 


\subsection{Discussion of Results}

As for the predictive power tests, no significant difference was found between the two accounting metrics, hence there was insufficient evidence to make conclusions on whether NI was better than $\mathrm{CI}$, and vice versa. Nevertheless, even though the difference between NI and CI was not significant in terms of predictive power, the results showed that the CI did not possess more predictive power than NI. One plausible explanation for this may be that the financial instrument securities formed a sizeable portion of the assets for financial firms. Hence, the OCI items tended to be more transitory and volatile in nature. This is due to the financial instruments' higher exposure to unrealised fair value changes. Consequently, these $\mathrm{OCI}$ items were subjected to higher measurement errors, thereby hurting the predictive power of the CI.

Moving to the value relevance tests, the results demonstrated that NI was better than CI; it was statistically significant for both the price and return models. This indicates that the traditional accounting metrics of NI is superior to CI. This may suggest that the OCI items, being more transitory and volatile in nature, were not perceived by investors to be incrementally useful for decision-making. This outcome is in line with prior studies (Dhaliwal et al., 1999; Goncharov \& Hodgson, 2011; Mechelli \& Cimini, 2014; Veltri \& Ferraro, 2018) which posited that less transitory and less volatile items would yield more value relevant results. Abdullah et al. (2015) had mentioned that Type II agency problems surround the Malaysian context due to its unique institutional settings, such as high ownership structures. In addition, the weaker legal enforcement it experiences also reduced investors' demand for quality reporting (Abdullah et al., 2015; Ball et al., 2003; Fan \& Wong, 2002). This, therefore, led to higher earnings management activities. Consequently, the OCI items for financial firms (more transitory and volatile in nature due to the higher exposure to financial instrument components) may have been deemed to be less reliable, hence less decision useful for investors. As such, investors continued to attach more value to NI than CI.

\section{Conclusion}

This study had examined the decision usefulness, namely predictive power and value relevance, of NI as compared to CI. Past studies on fair value reporting were focused mainly in developed economies where findings may not be generalisable to emerging Asian economies 
like Malaysia. This study aimed to make contributions to literature on decision usefulness of $\mathrm{CI}$ by attempting to gather empirical evidence from the Malaysian context which has smaller and less efficient economies (Gan et al., 2016).

Focusing on future cash flows and future earnings, the findings showed that both predictive power tests were not statistically different. Thus, it could not be concluded that one accounting metric has better predictive power than the other. As for value relevance, the results demonstrated that the NI was better than $\mathrm{CI}$ when using the price model, significance was at the 0.01 level. Additional robustness test using the return model also suggested that the NI was more value relevant than $\mathrm{CI}$, and it was significant at 0.05 level. Therefore, it can be deduced that NI dominates $\mathrm{CI}$ as a decision-relevant metric for investors who may attach more emphasis on the traditional accounting metric of NI when making investment decisions as opposed to CI. This occurrence may be attributed to the unique institutional setting of high ownership concentration structure coupled with generally weaker legal enforcement, both of which led to higher earnings management activities in Malaysia as compared to developed countries, such as the UK, US, and Europe. The OCI items which were more transitory and volatile in nature, caused by the high exposure to unrealised fair value changes of financial instruments, therefore, may not be perceived to be reliable and decision useful for investors. As such, investors continue to attach more value to the NI as opposed to CI.

\subsection{Implications of the Findings}

The findings of this study provide a number of implications. First, the findings showed that NI dominated CI as a decision-relevant metric for both the price and return models. This suggests that NI was valued more positively than $\mathrm{CI}$ by investors. Investors who were involved in valuing securities for their day-to-day decision-making in Malaysia may find this study relevant and timely. They could make use of these findings to make better investment decisions.

The standard setters such as IASB and MASB may also benefit from this study which offers empirical evidence of accounting disclosures made under the MFRS 101 standard, which is equivalent to the revised IAS 1 (2007). Focusing on the Malaysian context, this study offers insights into the institutional settings (e.g., ownership structures and legal enforcement) which are significantly different from developed 
countries (e.g., US, UK and Europe). Standard setters may also benefit from the findings which can be used to constantly improvise on the quality of financial reporting so as to provide accounting information that is relevant to a larger audience, both for emerging and less developed countries.

This study may also be of advantage to academicians. First, the outcome derived adds to the current literature on decision usefulness of FVA for an emerging economy. As such, Malaysia serves as an example. Second, the outcome serves as a reference point for future research work, thereby broadening research on the decision usefulness of $\mathrm{CI}$ in other jurisdictions, particularly to the financial sector. Thus far, evidence in this respect has been lacking. Third, the outcome may be used by academicians in consultation with the Malaysian Institute of Accountants (MIA) for the development of relevant policies and plans in improving financial reporting practices in Malaysia.

The regulators and policymakers (e.g., Bursa Malaysia and Securities Commission) may also find the findings useful for evaluating the decision usefulness of the new accounting metric of CI. Further enforcement policies on the quality of financial reporting can thus be motivated through improving the decision usefulness of the financial reporting information for investors.

\subsection{Limitations and Suggestions for Future Research}

This study is limited by the small sample size used, thereby affecting the generalisability of the findings. Only 29 Malaysian listed firms were examined and only six years of data (2012 to 2017) were generated for this study, following the adoption of the Statement of Comprehensive Income under MFRS 101 in 2012, which is equivalent to IAS 1 (revised 2007). Since the study had only focused on examining the decision usefulness of $\mathrm{CI}$ for the Malaysian financial sector, findings may not be generalisable to other countries and jurisdictions, therefore, these areas should be covered by future research.

It is also recommended that future research expand on the sample size by extending on the number of years since new data would be available. There are several advantages to these. First, by using a longer period when more data is available, the results would be more robust. Second, this study uses only one-year-ahead earnings and operating cash flows to measure the impact on predictive power. Future research may consider using a longer time period (i.e., three-year-ahead) to 
measure the impact on predictive power as some of the OCI items, particularly the financial instrument's components, may be held for a longer period of time by firms (Palea \& Scagnelli, 2017). Third, future research could also be conducted using data from other countries, as a comparison with Malaysia, to assess if the outcome is applicable to other jurisdictions.

\section{References}

Abdullah, M., Evans, L., Fraser, I., \& Tsalavoutas, I. (2015). IFRS mandatory disclosures in Malaysia: The influence of family control and the value (ir)relevance of compliance levels. Accounting Forum, 39(4), 328-348. http://dx.doi.org/10.1016/j.accfor.2015.05.003

Acaranupong, K. (2017). Accounting practices and value relevance of investment property: Evidence from firms listed on the stock exchange of Thailand. Asian Journal of Business and Accounting, 10(2), 1-41.

Ahmad, S.Z.S., Hassan, M.S., \& Jaffar, R. (2016). Chief executive officer/ managing director succession and value relevance of accounting numbers. Asian Journal of Accounting and Governance, 7, 25-40. http://dx.doi. org/10.17576/ AJAG-2016-07-03

Al-dhamari, R.A., \& Ku Ismail, K.N.I. (2013). Governance structure, ownership structure and earnings predictability: Malaysian evidence. Asian Academy of Management Journal of Accounting and Finance, 9(1), 1-23. Retrieved from https:// ssrn.com/abstract $=2945299$

Al-Yaseen, B.S., \& Al-Khadash, H.A. (2011). Risk relevance of fair value income measures under IAS 39 and IAS 40. Journal of Accounting in Emerging Economies, 1(1), 9-32. http://dx.doi.org/10.1108/20421161111107831

Ali, A., Chen, T.-Y., \& Radhakrishnan, S. (2007). Corporate disclosures by family firms. Journal of Accounting and Economics, 44(1-2), 238-286. http://dx.doi. org/10.1016/j.jacceco.2007.01.006

Ball, R. (2006). International Financial Reporting Standards (IFRS): Pros and cons for investors. Accounting and Business Research, 36(sup1), 5-27. http:// dx.doi.org/10.1080/00014788.2006.9730040

Ball, R., Kothari, S.P., \& Robin, A. (2000). The effect of international institutional factors on properties of accounting earnings. Journal of Accounting and Economics, 29(1), 1-51. http://dx.doi.org/10.1016/S0165-4101(00)00012-4

Ball, R., Robin, A., \& Wu, J.S. (2003). Incentives versus standards: Properties of accounting income in four East Asian countries. Journal of Accounting and Economics, 36(1-3), 235-270. http://dx.doi.org/10.1016/j.jacceco.2003.10.003

Baltagi, B.H. (2008). Econometric analysis of panel data. Chichester, West Sussex: John Wiley \& Sons.

Bar-Yosef, S., \& Prencipe, A. (2013). The impact of corporate governance and earnings management on stock market liquidity in a highly concentrated 
ownership capital market. Journal of Accounting, Auditing \& Finance, 28(3), 292-316. http://dx.doi.org/10.1177/0148558X13492591

Barth, M.E., Beaver, W.H., \& Landsman, W.R. (2001). The relevance of the value relevance literature for financial accounting standard setting: Another view. Journal of Accounting and Economics, 31(1-3), 77-104. http://dx.doi. org/10.1016/S0165-4101(01)00019-2

Barth, M.E., Gomez-Biscarri, J., Kasznik, R., \& López-Espinosa, G. (2017). Bank earnings and regulatory capital management using available for sale securities. Review of Accounting Studies, 22(4), 1761-1792. http://dx.doi. org/10.1007/s11142-017-9426-y

Barth, M.E., Landsman, W.R., \& Lang, M.H. (2008). International accounting standards and accounting quality. Journal of Accounting Research, 46(3), 467498. http://dx.doi.org/10.1111/j.1475-679X.2008.00287.x

Barth, M.E., Landsman, W.R., \& Wahlen, J.M. (1995). Fair value accounting: Effects on banks' earnings volatility, regulatory capital, and value of contractual cash flows. Journal of Banking \& Finance, 19(3-4), 577-605. http://dx.doi.org/10.1016/0378-4266(94)00141-O

Bratten, B., Causholli, M., \& Khan, U. (2016). Usefulness of fair values for predicting banks' future earnings: Evidence from other comprehensive income and its components. Review of Accounting Studies, 21(1), 280-315. http://dx.doi.org/10.1007/s11142-015-9346-7

Brown, P., \& Tarca, A. (2012). Ten years of IFRS: Practitioners' comments and suggestions for research. Australian Accounting Review, 22(4), 319-330. http://dx.doi.org/10.1111/j.1835-2561.2012.00198.x

Bursa Malaysia. (2019). Market capitalization. Retrieved March 27, 2019, from https://www.ceicdata.com/en/malaysia/bursa-malaysia-market capitaliza tion?page $=2$

Cahan, S.F., Courtenay, S.M., Gronnewoller, P.L., \& Upton, D.R. (2000). Value relevance of mandated comprehensive income disclosures. Journal of Business Finance \& Accounting, 27(9-10), 1233-1265. http://dx.doi.org/ 10.1111/1468-5957.00356

Campbell, J.L. (2015). The fair value of cash flow hedges, future profitability, and stock returns. Contemporary Accounting Research, 32(1), 243-279. http:/ / dx.doi.org/10.1111/1911-3846.12069

Chambers, D., Linsmeier, T.J., Shakespeare, C., \& Sougiannis, T. (2007). An evaluation of SFAS No. 130 comprehensive income disclosures. Review of Accounting Studies, 12(4), 557-593. http://dx.doi.org/10.1007/s11142-0079043-2

Cheah, E.T. (2005). A quality award and stock market reaction: Evidence from Malaysia. Total Quality Management \& Business Excellence, 16(6), 681-691. http://dx.doi.org/10.1080/14783360500077328

Chen, C.J.P., Chen, S., \& Su, X. (2001). Is accounting information value-relevant in the emerging Chinese stock market? Journal of International Accounting, 
Auditing and Taxation, 10(1), 1-22. http://dx.doi.org/10.1016/S1061-9518 (01)00033-7

Choi, J.-H., Das, S., \& Zang, Y. (2007). Comprehensive income, future earnings, and market mispricing (Working Paper no. 3-2007). Singapore: Singapore Management University. Retrieved from https://ink.library.smu.edu.sg/ cgi/viewcontent.cgi?article $=1161 \&$ context=soa_research

Claessens, S., Djankov, S., \& Lang, L.H.P. (2000). The separation of ownership and control in East Asian corporations. Journal of Financial Economics, 58(12), 81-112. http://dx.doi.org/10.1016/S0304-405X(00)00067-2

Dechow, P.M. (1994). Accounting earnings and cash flows as measures of firm performance: The role of accounting accruals. Journal of Accounting and Economics, 18(1), 3-42. http:/ / dx.doi.org/10.1016/0165-4101(94)90016-7

Dhaliwal, D., Subramanyam, K.R., \& Trezevant, R. (1999). Is comprehensive income superior to net income as a measure of firm performance?. Journal of Accounting and Economics, 26(1-3), 43-67. http://dx.doi.org/10.1016/ S0165-4101(98)00033-0

Duh, R.R., Hsu, A.W.H., \& Alves, P.A.P. (2012). The impact of IAS 39 on the riskrelevance of earnings volatility: Evidence from foreign banks cross-listed in the USA. Journal of Contemporary Accounting \& Economics, 8(1), 23-38. http://dx.doi.org/10.1016/j.jcae.2012.03.002

Easton, P., \& Zhang, X.-J. (2017). Mixing fair-value and historical-cost accounting: Predictable other-comprehensive-income and mispricing of bank stocks. Review of Accounting Studies, 22(4), 1732-1760. http://dx.doi.org/ 10.1007/s11142-017-9423-1

Elshandidy, T. (2014). Value relevance of accounting information: Evidence from an emerging market. Advances in Accounting, 30(1), 176-186. http://dx.doi. org/10.1016/j.adiac.2014.03.007

Fan, J.P.H., \& Wong, T.J. (2002). Corporate ownership structure and the informativeness of accounting earnings in East Asia. Journal of Accounting and Economics, 33(3), 401-425. http://dx.doi.org/10.1016/S0165-4101(02) 00047-2

Gan, C.Y., Chong, L.L., \& Ahmad, Z. (2016). Impacts of FRS139 adoption on value relevance of financial reporting in Malaysia. Managerial Finance, 42(7), 706-721. http://dx.doi.org/10.1108/MF-06-2015-0167

Goncharov, I., \& Hodgson, A. (2011). Measuring and reporting income in Europe. Journal of International Accounting Research, 10(1), 27-59. http:// dx.doi.org/10.2308/jiar.2011.10.1.27

Gujarati, D.N. (2009). Basic econometrics (5th ed.). New Delhi, India: Tata McGraw-Hill Education.

Haniffa, R., \& Hudaib, M. (2006). Corporate governance structure and performance of Malaysian listed companies. Journal of Business Finance $\mathcal{E}$ Accounting, 33(7-8), 1034-1062. http://dx.doi.org/10.1111/j.1468-5957. 2006.00594.x 
Hassan, M.S., Mohd-Saleh, N., Rahman, A.F., \& Shukor, Z.A. (2016). Underinvestment and value relevance of earnings management. UKM Journal of Management, 46, 99-113.

Holthausen, R.W. (2009). Accounting standards, financial reporting outcomes, and enforcement. Journal of Accounting Research, 47(2), 447-458. http:// dx.doi.org/10.1111/j.1475-679X.2009.00330.x

Hussin, B.M., Ahmed, A.D., \& Teoh, C.Y. (2010). Semi-strong form efficiency: Market reaction to dividend and earnings announcements in Malaysian stock exchange. IUP Journal of Applied Finance, 16(5), 36-60.

IASB. (2018). Conceptual framework for financial reporting. London: International Accounting Standards Board.

Jensen, M.C., \& Meckling, W.H. (1976). Theory of the firm: Managerial behavior, agency costs and ownership structure. Journal of Financial Economics, 3(4), 305-360. http://dx.doi.org/10.1016/0304-405X(76)90026-X

Kabir, H.M., \& Laswad, F. (2011). Properties of net income and total comprehensive income: New Zealand evidence. Accounting Research Journal, 24(3), 268-289. http://dx.doi.org/10.1108/10309611111187000

Kanagaretnam, K., Mathieu, R., \& Shehata, M. (2009). Usefulness of Comprehensive Income reporting in Canada. Journal of Accounting and Public Policy, 28(4), 349-365. http://dx.doi.org/10.1016/j.jaccpubpol.2009.06.004

Kothari, S.P., \& Zimmerman, J.L. (1995). Price and return models. Journal of Accounting and Economics, 20(2), 155-192. http://dx.doi.org/10.1016/01654101(95)00399-

Leuz, C. (2006). Cross listing, bonding and firms' reporting incentives: A discussion of Lang, Raedy and Wilson (2006). Journal of Accounting and Economics, 42(1-2), 285-299. http://dx.doi.org/10.1016/j.jacceco.2006.04.003

Leuz, C., Nanda, D., \& Wysocki, P.D. (2003). Earnings management and investor protection: An international comparison. Journal of Financial Economics, 69(3), 505-527. http://dx.doi.org/10.1016/S0304-405X(03)00121-1

Liew, P.K. (2007). Corporate governance reforms in Malaysia: The key leading players' perspectives. Corporate Governance: An International Review, 15(5), 724-740. http://dx.doi.org/10.1111/j.1467-8683.2007.00618.x

Lin, S., Martinez, D., Wang, C., \& Yang, Y. (2018). Is other comprehensive income reported in the income statement more value relevant? The role of financial statement presentation. Journal of Accounting, Auditing \& Finance, 33(4), 624-646. http:/ / dx.doi.org/10.1177/0148558X16670779

Maigoshi, Z.S., Latif, R.A., \& Kamardin, H. (2018). Change in value-relevance of disclosed RPT across accounting regimes: Evidence from Malaysia. Research in International Business and Finance, 44, 422-433. http://dx.doi. org/10.1016/j.ribaf.2017.07.114

Malkiel, B.G., \& Fama, E.F. (1970). Efficient capital markets: A review of theory and empirical work. The Journal of Finance, 25(2), 383-417. http://dx.doi. org/10.1111/j.1540-6261.1970.tb00518.x 
Mechelli, A., \& Cimini, R. (2014). Is comprehensive income value relevant and does location matter? A European study. Accounting in Europe, 11(1), 59-87. http://dx.doi.org/10.1080/17449480.2014.890777

Muniandy, B., \& Ali, M.J. (2012). Development of financial reporting environment in Malaysia. Research in Accounting Regulation, 24(2), 115-125. http:// dx.doi.org/10.1016/j.racreg.2012.05.004

Odia, J.O., \& Ogiedu, K.O. (2013). IFRS adoption: Issues, challenges and lessons for Nigeria and other adopters. Mediterranean Journal of Social Sciences, 4(3), 389-399. http://dx.doi.org/10.5901/mjss.2013.v4n3p389

Ohlson, J.A. (1995). Earnings, book values, and dividends in equity valuation. Contemporary Accounting Research, 11(2), 661-687. http://dx.doi.org/10. 1111/j.1911-3846.1995.tb00461.x

Palea, V., \& Scagnelli, S.D. (2017). Earnings reported under IFRS improve the prediction of future cash flows? Evidence from European banks. Australian Accounting Review, 27(2), 129-145. http://dx.doi.org/10.1111/auar. 12115

Pronobis, P., \& Zülch, H. (2010). The predictive power of comprehensive income and its individual components under IFRS. SSRN Electronic Journal. http:// dx.doi.org/10.2139/ssrn.1576384

Salvato, C., \& Moores, K. (2010). Research on accounting in family firms: Past accomplishments and future challenges. Family Business Review, 23(3), 192215. http://dx.doi.org/10.1177\%2F0894486510375069

Samaha, K., \& Khlif, H. (2016). Adoption of and compliance with IFRS in developing countries. Journal of Accounting in Emerging Economies, 6(1), 3349. http://dx.doi.org/10.1108/JAEE-02-2013-0011

Soderstrom, N.S., \& Sun, K.J. (2007). IFRS adoption and accounting quality: A review. European Accounting Review, 16(4), 675-702. http://dx.doi.org/ $10.1080 / 09638180701706732$

Tam, O.K., \& Tan, M.G.S. (2007). Ownership, governance and firm performance in Malaysia. Corporate Governance: An International Review, 15(2), 208-222. http://dx.doi.org/10.1111/j.1467-8683.2007.00555.x

Tan, L.T. (2014). Financial accounting and reporting in Malaysia (5th ed.). Kuala Lumpur: $\mathrm{CCH}$ Asia Pte Limited.

Veltri, S., \& Ferraro, O. (2018). Does other comprehensive income matter in credit-oriented systems? Analyzing the Italian context. Journal of International Accounting, Auditing and Taxation, 30(March), 18-31. http://dx.doi. org/10.1016/j.intaccaudtax.2017.12.006

Villalonga, B., \& Amit, R. (2006). How do family ownership, control and management affect firm value? Journal of Financial Economics, 80(2), 385417. http://dx.doi.org/10.1016/j.jfineco.2004.12.005

Vuong, Q.H. (1989). Likelihood ratio tests for model selection and non-nested hypotheses. Econometrica, 57(2), 307-333. http://dx.doi.org/10.2307/ 1912557 
Wüstemann, J., \& Kierzek, S. (2006). True and fair view revisited - A reply to Alexander and Nobes. Accounting in Europe, 3(1), 91-116. http://dx.doi. org/10.1080/09638180600920236

Zhong, L., Chourou, L., \& Ni, Y. (2017). On the association between strategic institutional ownership and earnings quality: Does investor protection strength matter? Journal of Accounting and Public Policy, 36(6), 429-450. http://dx.doi.org/10.1016/j.jaccpubpol.2017.09.002

\section{Appendix 1}

\section{List of Sample Firms}

1. Alliance Bank Malaysia Bhd

2. Aeon Credit Service Bhd

3. Affin Holdings Bhd

4. Allianz Malaysia Bhd

5. AMMB Holdings Bhd

6. Apex Equity Holdings Bhd

7. BIMB Holdings Bhd

8. Bursa Malaysia Bhd

9. CIMB Group Bhd

10. ECM Libra Financial Group Bhd

11. Hong Leong Bank Bhd

12. Hong Leong Capital Bhd

13. Hong Leong Financial Group Bhd

14. Insas Bhd

15. Johan Holdings Bhd
16. Kenanga Investment Bank Bhd

17. LPI Capital Bhd

18. Manulife Holdings Bhd

19. Malayan Banking Bhd

20. Malaysia Building Society Bhd

21. MNRB Holdings Bhd

22. MPHB Capital Bhd

23. Pacific and Orient Bhd

24. Public Bank Bhd

25. RCE Capital Bhd

26. RHB Bank Bhd

27. Syarikat Takaful Malaysia Bhd

28. TA Enterprise Bhd

29. Tune Protect Group Bhd 